\title{
Getting It Right and Getting It Wrong in Digital Archaeological Ethics
}

\author{
L. Meghan Dennis \\ The Alexandria Archive Institute/Open Context \\ lmeghandennis@gmail.com
}

\begin{abstract}
Though the ethics of archaeological practice have changed over the life of the discipline (and have arguably become more robust), full consideration has not yet been given to how digital methodologies and the emergence of digital technologies have created new areas requiring ethical introspection. The pace of adoption of digitally centred archaeological data and digitally facilitated archaeological practice has not been met by the adoption of discipline-wide standards related to archaeological ethics. The result of this mismatch in ethics and practice is the creation of archaeologists who utilize digital forms, but whose archaeology is ungrounded in frameworks that specifically consider the ethical burdens of digital tools, methodology, and theory. This chapter details views of digital archaeological ethics related to digital archaeology as tools, digital archaeology as methodology, and digital archaeological pedagogy.
\end{abstract}

How to cite this book chapter:

Dennis, L. M. 2021. Getting It Right and Getting It Wrong in Digital Archaeological Ethics. In: Champion, E. M. (ed.) Virtual Heritage: A Guide. Pp. 105-113. London: Ubiquity Press. DOI: https://doi.org/10.5334/bck.j. License: CC-BY-NC 


\section{Introduction}

As archaeologists, we operate from an inherent place of privilege regarding our access to direct evidence of the past. We get to handle, study, and analyse artefacts that for a variety of reasons, are not available to the public in the same way. Because of this privilege, we have what is called a 'duty of care' to act responsibly towards the sites we excavate, as well as to the public who relies on us to produce data that is accessible, understandable, and thoughtful. The chief way in which we consider whether we are meeting that responsibility is through our practice of 'archaeological ethics'.

Archaeological ethics are the discipline-wide standards that archaeologists have agreed to uphold. They inform everything from how new archaeologists are trained (Mills et al. 2008) to how excavation data is published (Kansa \& Kansa 2013) to how we work with paying clients and the many different publics that are the ultimate recipients of our knowledge production (Fowler 2017). However, these ethics are not static. As the discipline of archaeology has changed, so have the accepted ethical practices, as archaeologists have dealt with profound changes in the context of archaeology and profound changes in ethical concerns (Wylie 1996).

Most recently, archaeologists have begun to consider the ethical implications of the digital in our work. This has come in many ways, two of which we will discuss in more depth. The first issue is how archaeological ethics should consider the digital tools that we use. The second issue is how archaeological ethics should consider the digital methodologies we employ. A critical, though as yet under-discussed, third issue is how we should consider archaeological education and the digital. (This third issue is what we sometimes call 'digital archaeological pedagogy.')

As a dedicated practice, digital archaeology is too recent to be included in the published guidelines and codes of ethics that are provided by organizations such as the Society for American Archaeology (SAA), the Society for Historical Archaeology (SHA), and the European Association of Archaeologists (EAA). This does not mean that digital archaeologists should operate without ethical oversight though! Digital archaeology has expanded into mainstream archaeology, and the ethics of practice of that expansion have just not been kept up with by the professional organizations in their documentation (Dennis 2020).

One of the first discussions of what would result in 'digital' archaeology occurred in 1967, when Chenhall considered the electronic computer as a tool for data storage and retrieval (Chenhall 1967). Cowgill, also that year, discussed the introduction of computers for statistical and computational analysis (Cowgill 1967), and between the two, the push to a digital archaeology had begun. A series of arguments for and against the use of computers in archaeology occurred throughout the 1970s, and by the 1980s there was an explosion of computer-based archaeological data production. This is when total data stations and GIS began to enter archaeology. By 1992 the concept of a 
digital archaeology and digital archaeologists had become prevalent enough to support the founding of the Computer Applications \& Quantitative Methods in Archaeology organization (CAA), a professional group focused on digital archaeology. A digital archaeology interest group followed shortly after within the SAA. Despite all that, it was not until 2003 that the first direct mention of ethics in digital archaeology was published (Bayliss 2003). Even then, CAA did not have a dedicated ethics policy for digital archaeology until 2018, and SAA and EAA still do not, though both organizations are in the process of updating their codes of ethics more broadly as of 2021.

\section{Current Archaeological Ethics}

There are two circumstances under which most archaeologists encounter formal processes of archaeological ethics. The first circumstance is through the need to comply with mandated ethics frameworks, usually provided by universities and research bodies who grant funding. These organizations ask archaeologists, both as student researchers and as faculty researchers, to detail how we're going to undertake our projects, and how we're considering ethics in those projects.

The second circumstance is less common, but is on the rise, and occurs when archaeologists meet at professional conferences or submit papers for publication. Professional organizations, like the previously mentioned SAA, SHA, EAA, and CAA groups, ask members to follow what are known as 'aspirational' codes of ethics.

Aspirational codes of ethics are intentionally general and are meant to apply to the majority of archaeological projects that follow the traditional physical excavation and journal publication model of archaeology. Aspirational codes of ethics are sometimes called 'principles', as they're not meant to dictate behaviour, but to 'define general and fundamental propositions that affirm the tents of the profession, which can be adopted to guide action in a wide variety of specific settings' (Colwell-Chanthaphonh \& Ferguson 2006: 116-117). Failure to meet an organization's code of ethics has few, if any, consequences under an aspirational system. It is assumed that violations will be handled more formally by universities and employers. This is sometimes sufficient, but not always.

Within archaeology it has historically been the case that ethical behaviour is believed to be assured by an archaeologist's participation in professional membership societies and that the field should set its own standards of acceptable and unacceptable practice. Aspirational codes of ethics typically fulfil this role, due to archaeology's relationship with academic departments and organizations.

In contrast to aspirational codes of ethics, 'prescriptive' codes of ethics are more like systems of rules. A prescriptive code of ethics specifically lists acceptable and unacceptable behaviours within the discipline. As an example, the Code of Conduct and Standards of Research Performance of the Register of 
Professional Archaeologists (RPA) is purposefully prescriptive, listing what an archaeologist 'shall' and 'shall not' do (RPA 2018). These standards are enforced via a grievance process, which is overseen by an elected officer whose role is to handle, 'allegations of violations of the Code of Conduct and Standards of Research Performance of the Register, in accordance with the Disciplinary Procedures of the Register' (RPA 2018). Prescriptive codes of ethics are more common in organizations that deal with contract or commercial archaeology, such as the Register of Professional Archaeologists and the Chartered Institute for Archaeologists (CIfA).

Because the ethics of digital archaeology are not provided as aspirational suggestions of 'good behaviour' and 'bad behaviour' nor as prescriptive directives of 'shall' and 'shall not', the onus is on those who work in digital archaeology to more carefully consider how they view their ethical relationship with the three areas of digital archaeological practice: digital tools in archaeology, digital methodologies in archaeology, and the digital education of archaeologists. We will turn now to discussing each of these areas.

\section{Digital Tools in Archaeology}

One view of digital archaeology holds that the digital aspects of archaeological practice should be considered tools (Zubrow 2006). This view holds that the use of a program such as QGIS, for spatial and relational mapping, or a digital camera and Adobe Photoshop, for site photography and creating a digital site archive, or a laser scanner, to create point clouds for 3D modelling of historic structures, are tools, to be used by archaeologists to meet an end, but without any larger ethical implications. They are equated to the trowel, the measuring tape, and the Munsell Soil Color Charts, in that they are utilized for a specific function, and their digital nature is irrelevant to the impact of their use on the completed archaeology.

While this view is not inherently incorrect, there is a danger in assuming that the ethics of using a digital tool are the same as the ethics of using a manual tool. Both digital and manual need to be considered in light of their 'ethical burdens'. An ethical burden is the weight an archaeologist must give to whether any given thing is ethically appropriate, or inappropriate. As an example, the ethical burden of a trowel is typically low for archaeologists; it is regularly a necessary tool to be used in the process of excavation. However, if the use of the trowel in an excavation would disenfranchise indigenous peoples through unwanted exhumations of human remains, the ethical burden of the trowel becomes much greater.

A common problem with ethical burden and digital tools in archaeology is what is referred to as 'black box' technologies. A black box is an object, piece of software, or system in which the user can direct input but cannot examine or verify the processes that occur before the produced output. Some potentially 
black-box digital tools in archaeology include the previously mentioned digital photography, geographic information systems (GIS), and photogrammetry. Most of these tools are facilitated through proprietary software, where the code that creates the output cannot be viewed. For most archaeologists, even open source software packages, such as QGIS and R, are black boxes, as they are used without a full understanding of what underpins the packages.

For those interested in further discussion of the concept of a black box in archaeology, the topic has been discussed extensively via discussions of Latour (1987), and more recently and applicably by Huggett (2017) and Caraher (2016: 434). Caraher explains its use in digital archaeology as the result of:

...growing pressures on both academic archaeologists and those in the field of cultural resource management to produce results at the pace of development and capital. In other words, as digital tools accelerate the pace of archaeological work, more aspects of archaeological practice become obscured by technology.

\section{Digital Methodologies in Archaeology}

Another view of digital archaeology holds that the digital aspects of archaeological practice should be considered for their value as methodological and theoretical approaches (Perry \& Taylor 2018). This view is concerned with how the digital is being deployed in research designs, and how digital archaeology is meeting larger issues related to public outreach and interaction with marginalized and indigenous populations. Again, we turn to the concept of ethical burden.

When considering digital archaeology as a methodological approach, the ethical burden occurs almost immediately, during planning at the outset of the project. Digital methodologies should be subject to the same level of ethical scrutiny as the use of any manual toolset or analog methodological approach. A series of simple questions, asked at the beginning of research design planning, may result in the addition, or elimination, of digital aspects of the project.

For every tool under consideration, we should ask, 'Is the use of this tool in a digital form adding value to the project that is balanced by the ethics of its use?' For every methodological consideration, we should ask, 'Is this approach, mediated digitally, fulfilling all of our needs for it, without adding undue ethical burden or breach?' If the answer to either of those questions is no, the use of the digital form should be weighed against the analog form.

Just because something can be accomplished faster, or easier, with a digital approach, doesn't mean that the ethics of that approach are equal! The ethical burden might be too high. Understanding how that burden is borne by methodological and practical choices is the responsibility of everyone on a project. 
As an example, consider a project involving human remains. There are potentially widely different ethical considerations between an analog methodology and a digital methodology (Ulguim 2018).

In an analog methodology, human remains are excavated, laid out (if possible) for examination by an osteoarchaeologist, photographed, and either stored physically for future study or re-interred. The data that is collected from analysis of the remains is a tangible, physical dataset, and who can interact with both the remains and the dataset is access limited. The longevity of the dataset is determined by how well the physical medium in which it exists is maintained. In this situation, the ethical burden on those involved with the project is to fulfil their research agenda while treating the remains with dignity and to do so (if applicable) through consultation that respects the wishes and cultural rights of descendant populations.

In a digital methodology, human remains are excavated, laid out (if possible) for examination by an osteoarchaeologist, photographed, scanned for 3D modelling, sampled for digitally mediated analysis, and either stored physically for future study or re-interred. Digital records are produced of the remains, and digital copies may be created of the remains to be manipulated for methodological testing models and to be made available to the public via outreach and museological interactives. The data that is collected from the analysis of the remains is a collection of digital files, and though who can interact with the remains is access limited, the digital files are often distributed more openly. The longevity of the dataset is determined by how dispersed the digital files are and how long the digital formats in which they are stored are viable, technologically. In this situation, the ethical burden on those involved with the project is the same as in an analog methodology, but with the added burdens of negotiating the potential differences in views towards digital permanence by indigenous populations and marginalized populations.

No widespread study on how indigenous groups view their rights regarding digital archaeology related to their ancestors has been undertaken within archaeology and the ethics of digital archaeology related to human remains is being determined largely by non-indigenous archaeologists. A special issue of Archaeologies (Alfonso-Durruty et al. 2018; Hassett et al. 2018; Hirst, White \& Smith 2018; Ulguim 2018; White, Hirst \& Smith 2018) is the most thorough discussion to date concerning these issues.

\section{Digital Education in Archaeology}

Though archaeologists differ in their views of digital archaeologies as tools or methodologies, they share a common foundation in the process of education that leads to their professionalization within the discipline (Shaeffer 2016). How digital archaeology is conveyed to students, whether as tool or methodology, is arguably less important than that it is being conveyed to students, and 
that it is preparing them for the reality of the digitally mediated archaeology that is modern practice. Problems occur, however, when students are taught to use digital tools without teaching the accompanying ethical consideration of those tools (Dennis 2020). Students need to be educated in a process of ethical questioning concerning their digital outputs and in the resources available to address those questions.

The practical issues that professional archaeologists encounter, both in academia and commercial practice, are common to issues encountered by student archaeological researchers. These include issues in approaching and consulting with the public, issues in utilizing technology and digital tools, issues in decision-making concerning data storage and deposition, and issues in publishing and outreach, amongst others. All of the ethical issues present in these situations for more advanced practitioners are there for student researchers, but students must frequently negotiate these ethical concerns without recourse to networks of colleagues for consultation, or professional memberships for guiding principles.

Graduate students are often asked to consider the ethics of their practice through submissions to ethics review boards; however, that is frequently the first time that students encounter practical ethics in archaeology. Increased attention to undergraduate and entry graduate student-level interactions with ethics in digital archaeology, combined with an increased focus on the ethics of digital archaeology among those tasked with teaching students, is necessary to create a corpus of practitioners who are fully versed in the ethics of their profession.

As students, and as educators, we have a shared responsibility to push the discipline of archaeology forward into a more equitable, ethical practice. Part of this shared responsibility means publishing the whys and hows of the digital practice we undertake. There is little peer-reviewed literature around teaching ethics to archaeology students concerning digital applications, which means that educators have few sources to draw on to inform their teaching practice and to share with students to demonstrate best practices. Notable exceptions to this include Perry (2018) on humanizing digital archaeological and heritage practice, Graham (2016) on the creation of digital humanities notebooks, the work of participants in MSUDAI (2015) on collaborative cohorts in digital archaeological projects, and Cook (2018) on working with students to create ethically grounded digital exhibitions for museums.

\section{Conclusions}

Though the considerations of ethics within archaeology have arguably become more robust through the discipline's evolution, and digital archaeology has become more standard practice within the discipline, digital tools and digital methodologies have yet to be synthesized fully into archaeological discussion. 
Alongside this, the pace of adoption of digitally centred archaeological data and digitally facilitated archaeological practice has not been met by the adoption of discipline-wide standards related to archaeological ethics. The result of this mismatch in ethics and practice shows itself most clearly in the pedagogy of digital archaeology, where little literature exists to educate newly inducted archaeologists who utilize digital forms.

Digital archaeologists, and indeed all of us who are engaged with archaeology as professionals, have a responsibility to consider the ethical burdens of our research, as well as the tools and methodologies that we utilize to accomplish our knowledge production goals. It will be only through a shared effort that digital archaeology will come to be on par in terms of ethical consideration with established practices in excavation, analysis, publication, outreach, and education.

\section{References}

Alfonso-Durruty, M, Morello, F, Misarti, N, Vilar, M G, and Headley, D 2018 Protocol, potentials, and limitations of ancient teeth 3D printing. Archaeologies, 1-18. DOI: https://doi.org/10.1007/s11759-018-9345-y

Bayliss, R 2003 Archaeological survey and visualisation: The view from Byzantium. Late Antique Archaeology, 1(1): 26-313. DOI: https://doi.org /10.1163/22134522-90000012

Caraher, W 2016 Slow archaeology: Technology, efficiency, and archaeological work. In: E.W. Averett, J.M. Gordon, and D.B. Counts (eds.) Mobilizing the Past for a Digital Future: The Potential of Digital Archaeology, Grand Forks: The Digital Press @ The University of North Dakota. 421-41. DOI: https: //doi.org/10.17613/M6ZG8P

Chenhall, R G 1967 The description of archaeological data in computer language. American Antiquity, 161-167.

Colwell-Chanthaphonh, C and Ferguson, T J 2006 Trust and archaeological practice: Towards a framework of virtue ethics. The Ethics of Archaeology: Philosophical Perspectives on Archaeological Practice, 115-130. DOI: https: //doi.org/10.1017/CBO9780511817656.007

Cook, K 2018 Hacking classrooms for communities: Augmenting collaboration through digital scholarship. In: D.E. Cologne Communicating the Past in the Digital Age, 13 October 2018.

Cowgill, G 1967 Computer applications in archaeology. Computers and the Humanities, 2(1): 17-23. DOI: http://www.jstor.org/stable/30203945

Dennis, L M 2020 Digital archaeological ethics: Successes and failures in disciplinary attention. Journal of Computer Applications in Archaeology, 3(1): 210-218. DOI: https://doi.org/10.5334/jcaa.24

Fowler, D D 2017 The co-development of CRM and archaeological ethics, 1974 to 2015. In: New Perspectives in Cultural Resource Management (pp. 85-97). Routledge. 
Graham, S 2016 Shawn Graham's Open Digital Humanities Notebook 2016-17. Available at: https://ir.library.carleton.ca/pub/14187

Hassett, B R, Rando, C, Bocaege, E, Durruty, M A, Hirst, C, Smith, S, Ulguim, P F, White, S, and Wilson, A 2018 Transcript of WAC 8 Digital Bioarchaeological Ethics Panel Discussion, 29 August 2016 and Resolution on Ethical Use of Digital Bioarchaeological Data. Archaeologies, 1-21. DOI: https://doi.org/10.1007/s11759-018-9343-0

Hirst, C S, White, S, and Smith, S E 2018 Standardisation in 3D geometric morphometrics: Ethics, ownership, and methods. Archaeologies, 1-27. DOI: https://doi.org/10.1007/s11759-018-9349-7

Huggett, J 2017 The apparatus of digital archaeology. Internet Archaeology, 44. DOI: https://doi.org/10.11141/ia.44.7

Kansa, E C and Kansa, S W 2013 Open archaeology: We all know that a 14 is a sheep: Data publication and professionalism in archaeological communication. Journal of Eastern Mediterranean Archaeology \& Heritage Studies, 1(1): 88-97. DOI: https://doi.org/10.5325/jeasmedarcherstu.1.1.0088

Latour, B 1987 Science in Action: How to Follow Scientists and Engineers through Society. Cambridge: Harvard University Press.

Michigan State University Institute on Digital Archaeology Method \& Practice (MSUDAI) 2015 Available at: http://digitalarchaeology.msu.edu/

Mills, B J, Altaha, M, Ferguson, T J, and Welch, J R 2008 Field Schools without trowels: Teaching archaeological ethics and heritage preservation in a collaborative context. In: Silliman, S.W. (Ed.), Collaborating at the Trowel's Edge: Teaching and Learning in Indigenous Archaeology. University of Arizona Press, Tucson. pp. 25-49.

Perry, S and Taylor, J 2018 Theorising the digital: A call to action for the archaeological community. In: M. Matsumoto \& E. Uleberg, eds. CAA2016, Oceans of Data: Proceedings of the 44th Conference on Computer Applications and Quantitative Methods in Archaeology. Oxford: Archaeopress, pp. 11-22.

Perry, S 2018 Why are heritage interpreters voiceless at the trowel's edge? A plea for rewriting the archaeological workflow. Advances in Archaeological Practice, 212-227. DOI: https://doi.org/10.1017/aap.2018.21

Register of Professional Archaeologists and the Chartered Institute for Archaeologists 2018 Archaeological Ethics Database. Available at: http: //archaeologicalethics.org/

Shaeffer, M K 2016 Professional Identity and Professionalization in Archaeology: A Sociological View (Doctoral dissertation, Kent State University).

Ulguim, P 2018 Models and metadata: The ethics of sharing bioarchaeological 3D models online. Archaeologies, 1-40. DOI: https://doi.org/10.1007 /s11759-018-9346-X

Zubrow, E 2006 Digital archaeology: A historical context. In: Thomas Evans and Patrick Daly, Digital Archaeology: Bridging Method and Theory, pp. 10-31. 